\title{
Bassanio's bailout: A brief history of risk, Shakespeare to Wall Street
}

\author{
Richard Halpern \\ New York University
}

\begin{abstract}
Shakespeare's most searching anatomy of risk, The Merchant of Venice depicts the wagering not only of money but of love and life itself. This paper places Merchant in a long history that traces the concept of risk from classical theatre to medieval scholasticism to modern sociology. Over the course of this history, the moral and economic dimensions of risk become increasingly fugitive and unmappable. Shakespeare's play illustrates this process in miniature, and in so doing casts light on our contemporary "risk society," including the financial meltdown of 2008.
\end{abstract}

KEYWORDS: William Shakespeare; risk; finance; Alexandre Kojève; G.F.W. Hegel; Ulrich Beck.

Given the perennial temptation on the part of academics, pundits, and supreme court judges alike to apply Shakespeare to contemporary events, it is surprising that so little hay has been made from The Merchant of Venice in the aftermath of the financial crisis of 2008. An article promisingly titled "The Merchant of Zucotti Park" did appear in the online version of The Chronicle of Higher Education in November 2011. But the author, disappointingly, turned out to be Peter Wood, president of the National Association of Scholars, a conservative group; and his main point (when he wasn't accusing the Occupy protestors of riot, arson, vandalism and rape) was to argue against the forgiving of student debt then being demanded by the OWS movement. For Wood, apparently, the quality of mercy is sometimes strained when it lets improvident young Bassanios and

(G) edert 24 (2014: 27-45)

https://doi.org/10.34136/sederi.2014.2 
Antonios off the hook for their college educations. As Shakespearean allegories go, this one had at least the virtue of being unexpected.

A more interesting application of Shakespearean wisdom actually predated the crisis of 2008. An article in the Wall Street Journal about John Geanakoplos, professor of economics at Yale and partner at Ellington Capital, mentions Geanakoplos' claim that rereading The Merchant of Venice in 1997 prompted him to reconsider the importance of collateral in financial markets and to formulate a theory of "leverage cycles" that ended up looking quite prescient in the aftermath of 2008. Other attempts to connect Shakespeare's play and the 2008 financial meltdown have mostly inhabited the lower and seamier regions of the blogosphere, and I will not recount them here.

While I don't think that The Merchant of Venice can tell us anything about the meltdown that we didn't already know, I do think that the meltdown may alert us to some previously undernoticed dimensions of Shakespeare's play. Moreover, The Merchant of Venice occupies a place in a deep conceptual history that led up to the events of 2008 and thereafter, and reconstructing that lineage is not without interest. What follows, then, is an (irresponsibly) abbreviated history of the concept of risk as it relates both to Shakespeare's play and to more contemporary events.

My conceptual starting point will be Alexandre Kojève's celebrated lectures on Hegel, which played such a central role in the intellectual life of Paris in the 1940s through the 196os. In the course of explicating Hegel's master-slave dialectic, Kojève observes:

For man to be truly human, for him to be essentially and really different from an animal, his human Desire must actually win out over his animal Desire. Now, all Desire is a desire for a value. The supreme value for an animal is its animal life. All the Desires of an animal are in the final analysis a function of its desire to preserve its life. Human Desire, therefore, must win out over this desire for preservation. In other words, man's humanity "comes to light" only if he risks his (animal) life for the sake of his human Desire. It is in and by this risk that the human reality is created and revealed as reality; it is in and by this risk that it "comes to light," i.e. is shown, demonstrated, verified, and gives proofs of being essentially different from the animal, natural reality. And that is why to speak of the "origin" of Self-Consciousness is 
necessarily to speak of the risk of life (for an essentially nonvital end). (1980:6-7)

Much in this passage will prove to be of interest for The Merchant of Venice, not only a play concerned with masters and slaves and with life and death, but one in which the relation between the human and the animal is repeatedly placed in question.

In Kojève's exposition, two battles rage simultaneously: first the concrete one between the primordial combatants, and second the more abstract one between animal and human desire. Both are decided at once: for the victorious Master, the essentially human desire for recognition has won out over animal self-preservation, the latter being apportioned to the defeated Slave who would not risk his life. For Kojève, then, risk is not just something that humans engage in. It is constitutive of the human as such, and of those dignified attributes such as self-consciousness and freedom that define the human. Through risk, the combatant transcends animal embodiment and animal desire without ever quite leaving them behind; through risk, the animal is in effect aufgehoben into the human.

Something strongly implicit in Kojève's exposition is that for the creation of the human to occur, subjective and objective risk must coincide. It is not enough, in other words, for the Master to believe he is risking his life; the latter must be objectively placed in the balance. Recognition is not simply a subjective impression or perception for Kojève but rather an objective situation, part of the Real; and this is consonant with Kojève's broader interpretation of the Hegelian dialectic (1980:169-259).

Neither Kojève nor Hegel for that matter associates the masterslave dialectic with a literary genre. But despite the obviously prototheatrical dimensions of a battle that centres on recognition, and thus converts one contestant into an audience for the other, I would suggest that the literary form most appropriate to this encounter is not drama but epic. Not that enslavement as such plays a prominent role in classical epic; but the battle to the death obviously does. By contrast, Greek tragedy seems relatively uninterested in risk. It can be found, of course: in Antigone's burial of Polyneices, for example, or in the classic Homeric encounters of Aeschylus's Seven against Thebes. Nevertheless, figures such as Oedipus and Pentheus, who undergo risk without knowing it, are more paradigmatic. Indeed, the 
separating out of subjective and objective risk which marks such characters is constitutive of tragic irony. The work of tragedy, we might say, is to disarticulate the epic unity of risk that marks both Homer and Hegel. Tragedy dwells more on mourning, the aftermath and consequence of risk, than it does on risk itself.

Unlike tragedy, Greek comedy is full of risks taken and avoided, but these lack tragic amplitude. Comic risk is not the risk of life, the only kind that counts for Kojève. In Greek drama, risk is therefore either disintegrated or diminished. Drama initiates a process in which epic risk is rendered increasingly complex, uncertain, and even fugitive. Risk is no longer something whole and self-evident but something that must be mapped, and which over time threatens to become unmappable. This fact is especially striking since, as a mode of performance, theatre is perhaps the riskiest of art forms, the one that most directly exposes its practitioners to either public ridicule or glory. If playwrights and actors do not face the loss of life, they certainly face the loss of face - and by the early modern period, the risk of economic failure as well. And yet this risky art form does not, at least in its Greek phase, particularly dwell on risk in its fictions. Perhaps this disproportion is theatre's own counterpart to tragic irony.

Even in the early modern period, it could be argued that epic and romance remain the supreme literary genres of risk. At the same time, risk also comes to play a greater role in tragic drama than it did for the Greeks. Yet it is in a comedy, if a problem comedy, that Shakespeare undertakes his great anatomy of risk. In The Merchant of Venice, not only do characters undergo risk; risk becomes, quite selfconsciously, a subject of analysis in which its nature and mappability are placed in question. The test of the caskets, insofar as it is a game of chance, renders risk as such thematically visible ("Who chooseth me must give and hazard all he hath"); and the play intertwines this with both financial risk and the Hegelian risk of life itself. Despite its virtual omnipresence, however, I want to argue that risk becomes maddeningly fugitive in the play. If risk is by definition the risk of loss, the loss faced by The Merchant of Venice is the loss of risk itself.

The word "risk" never actually appears in Shakespeare's play, although a raft of roughly synonymous terms fills in for it: hazard, venture, peril. But the play is virtually an enacted or dramatized etymology of risk. The medieval Latin term resicum or risicum starts 
appearing in the twelfth century in the Italian port cities of Pisa and Genoa, where it is used as a term in maritime commercial law indicating economic responsibility for future contingent events (Piron 2004:59-61). Shakespeare's play, set in the Mediterranean and concerned with maritime trade, thus occupies the geographical and economic birthplace of risk. The etymological origins of resicum are both murky and contested, but branch off in two main directions. One is to the Arabic word rizq, which can mean "the good apportioned by God to an individual," or in some Arab dialects a chance or favourable accident (Piron 2004:65-66). The Arabic term resembles in its semantic range the Latin portio or "portion" which may underlie the name Portia. Interestingly, the English term "hazard" also has an Arabic root, so perhaps it is appropriate that the first player in the test of the caskets is the Prince of Morocco.

An alternative derivation traces the word back to the Latin resecare, meaning "to cut or chop," a root of obvious relevance to the terms of the bond between Antonio and Shylock. Some lexicographers go so far as to connect the term with steep rocks that pose a risk to merchandise transported by ship, the "cut or chop" here being that which opens the bowels of the vessel. In this case, Salerio's whimsical musings about the source of Antonio's melancholy take us to the very heart of risk:

My wind cooling my broth

Would blow me to an ague, when I thought

What harm a wind too great might do at sea.

I should not see the sandy hour-glass run,

But I should think of shallows and of flats,

And see my wealthy Andrew dock'd in sand,

Vailing her high-top lower than her ribs

To kiss her burial. Should I go to church

And see the holy edifice of stone

And not bethink me straight of dangerous rocks,

Which touching but my gentle vessel's side,

Would scatter all her spices on the stream,

Enrobe the roaring waters with my silks,

And, in a word, but even now worth this,

And now worth nothing? Shall I have the thought

To think on this, and shall I lack the thought

That such a thing bechanced would make me sad?

But tell not me; I know, Antonio

Is sad to think upon his merchandise. (1.1.22-40) 
Thinking of risk, Salerio conjures its possible etymology in the fantasized scene of a merchant ship cut open by rocks. But this image simultaneously foreshadows a later fantasy, indeed the organizing one of the play: that of Antonio's body cut open by Shylock's knife. The wounded ship extruding spices and silks visually manifests the masochistic enjoyment or jouissance that inhabits that later fantasy as well. ${ }^{1}$ But in so doing, it also connects two unlikely spaces: the open sea and the courtroom, one lawless (described in The Winter's Tale as "unpath'd waters") and the other the very locus of law, one a natural emptiness and the other the most civilized of human institutions. ${ }^{2}$ Both, however, are spaces where characters encounter different kinds of risk. When Bassanio later refers to "merchant-marring rocks," he literalizes the connection between the marring of the merchant's ship and the marring of his body or person, thus sealing the connection between the hazards of the oceanic waste and that which Antonio faces in the courtroom.

Before turning in earnest to the play, I want to note some of the complexities surrounding what Michael Ferber (1990:446) calls "the ideology of risk" in its original, mercantile context. In theological debates, risk was used to justify the merchant's profits against the charge that he sold the same items that he bought, unchanged (Piron 2004:72-73). The "merchant adventurer," who ventures or risks his capital, thereby distinguished his justifiable profits from those of the usurer, who demands collateral and hence avoids risk. The scholastic philosopher Peter John Olivi took the notion of economic risk one step further when he defined it as involving not only the possible loss of one's principal but also the risk of failing to secure a reasonably expected profit. In other words, risk could now apply to merely virtual rather than actual sums. Olivi took this metaphysical nicety and gave it a theological turn when he explained the imputation of Christ's merit back onto Old Testament patriarchs by comparing it to profits which one expects to realize in the future (Piron 2004:74).

\footnotetext{
${ }^{1}$ On Antonio's masochism, see Daniel (2013:92-119).

${ }^{2}$ As Emmanuelle Collas-Heddeland et al. point out (2004:39), the word and concept of risk emerge in a period when the great maritime empires give way to northern civilizations focused on exploitation of the land - in other words, to a period in which sea travel comes to seem less familiar and more perilous.
} 
At the same time, the merchant's risks could be transferrable to other persons. Canon law held that there are cases in which loans to merchants are not considered usury because the success of the venture is uncertain and hence the lender undergoes risk (Piron 2004:72). In a sense, the usurer participates in the merchant's risk as Shylock does when he lends money to Antonio. And as Ferber (1990:438, n.10) points out, merchants tended to distribute risk by pooling their capital - a fact that Shakespeare avoids by having Antonio bear sole risk for his ships. My point is that mercantile theory and practice render the mapping of risk increasingly complex. Risk can be transferred, shared, even applied to unreal sums. The Merchant of Venice, I would argue, explores the moral and psychological implications of an increasingly fugitive risk.

The ironies of the play frequently center on separations of subjective from objective risk similar to those of Greek tragic drama. Shylock suffers unexpected risk and loss twice: first when he leaves Jessica to guard his household goods and second when he confidently enters the courtroom to collect his penalty from Antonio. Likewise, Antonio signs his bond with Shylock thinking that he undergoes no real risk since his wealth is distributed among several ships. In each case, the flesh of the unsuspecting character is mortgaged: Shylock loses his "flesh and blood" in Jessica and is threatened with actual death in the courtroom, and Antonio's bond almost costs him a mortal pound of flesh. While Shylock is simply unaware of the risks he faces, Antonio's situation is more complex. The bond with Shylock makes the terms of his risk explicit, and Antonio therefore knows that if he forfeits the bond he must pay with his body. But he chooses to ignore this because he views it as a mere legal formality and hence not actually realizable. He sees the risk but neutralizes it by making it into a mere virtuality or fiction. If Peter John Olivi turns the loss of merely expected or virtual sums into actual risk, Antonio reverses this by virtualizing the loss of real, extant wealth.

I want to follow the case of Antonio at greater length because it will lead us to forms of hazard that in their complexity go far beyond the "Greek" separation of subjective and objective risk. We can begin to assess Antonio's peril by comparing it to that described in Hegel's master-slave dialectic. The bond with Shylock raises mere financial risk to that of life itself; in Hegelian terms, Antonio proves his 
humanity by denying the basic animal instinct of self-preservation. Moreover, he does so to demonstrate his noble generosity to both Shylock and Bassanio - in other words, to gain recognition of his position as the master who is willing to risk. Thus far, a perfectly Hegelian scenario. Yet ironically, Antonio's sovereign gesture turns him into Shylock's slave rather than his master. According to the bond's terms, Shylock now "owns," if not Antonio's whole body, then at least a pound of it. When Antonio signs the bond he becomes Shylock's "bondsman," and Shylock understands this fully. This is why he answers the Venetians in the courtroom who demand Antonio's release with the counter-demand that they free their slaves. The risk of life ironically produces debasement rather than sovereignty. Or rather it produces both at once: a kind of "moral" mastery but physiological and legal slavery.

The play as a whole renders master-slave relations fundamentally unstable. Portia goes from mistress of Belmont to Bassanio's servant when she gives away both her person and fortune to him. When Bassanio wins her hand by risking all, she declares herself

Happiest of all [...] that her gentle spirit

Commits itself to yours to be directed,

As from her lord, her governor, her king.

Myself, and what is mine, to you and yours

Is now converted. (3.2.163-167)

But this reversal of positions is reversed again as Portia reclaims household sovereignty by play's end. Even Launcelot, the one actual servant in the play, becomes "Master Launcelot" in the game with his father. The positions of master and servant are unstable and labile in the play - never more so than when Antonio's risk allows him to attain to both at once.

But the most fundamental question surrounding Antonio is not whether risking his life has made him master or slave. Rather, it has to do with the question of whether loss of life is really the primary risk he faces. At the very least, Antonio demonstrates a Stoic resignation when he enters the courtroom in act four. But there is of course ample reason to believe that he is not merely reconciled to his fate but positively attached to it - that the thing he apparently dreads is also the thing he most fervently seeks. "Let me have judgment," he pleads, "and the Jew his will" (4.1.83). Certainly his 
death would yield benefits of various kinds. Playing the role of martyr allows Antonio to place the cruelty of Shylock as individual and of the Jews as a people on public display. It thus justifies his anti-Semitic hatred and fulfils his Christian ressentiment at the same time. On a sexual level, it satisfies the masochistic impulses that Antonio has exhibited throughout the play. And above all, it ties Bassanio to him forever in bonds of obligation, guilt and love:

Commend me to your honourable wife:

Tell her the process of Antonio's end;

Say how I loved you, speak me fair in death;

And, when the tale is told, bid her be judge

Whether Bassanio had not once a love.

Repent but you that you shall lose your friend,

And he repents not that he pays your debt;

For if the Jew do cut but deep enough,

I'll pay it presently with all my heart. (4.1.272-280)

And Bassanio responds just as Antonio wishes, declaring that he would sacrifice his wife to save his dear friend.

While death is a terrible thing, it offers Antonio so many kinds of satisfaction as to become irresistible. Antonio does risk his life, in good Hegelian fashion, but not in the name of heroic conquest. Rather, the "human" form of desire that transcends self-preservation here takes the form of a demand for recognition bound up with resentful, passive-aggressive, and masochistic urges. Whether this surpasses in nobility the realm of the animal that it leaves behind is far from clear. ${ }^{3}$

One result of Antonio's situation is to reinforce the resemblance to Shylock that has always subtended their conflict. In effect, Antonio and Shylock each think they are about to get something they deeply want: that is, Antonio's death. And each is about to be disappointed by Portia. The "risk" that Antonio actually undergoes, therefore, may not be the risk of life, but rather the risk that he will

\footnotetext{
${ }^{3}$ Unlike Antonio, Shylock cannot even rise to the level of attempting to risk his life. Threatened with death by the court, he collapses; and threatened immediately thereafter with the loss of his fortune, he complains "You take my life | When you do take the means whereby I live" (4.1.375-376). Unlike Antonio, who is willing to risk his life, Shylock is condemned to the animal realm of self-preservation. This is of course overlaid upon his status as the "carnal Jew" who cannot ascend to Antonio's Christian spirituality. And it comports with his repeated allusions to animals throughout the play.
} 
be prevented from risking his life. Portia, like the goddess Fortuna from whom her name may be derived, intervenes and - depending on one's perspective - either saves or defeats Antonio. ${ }^{4}$ While Shylock undergoes a classically ironic reversal in which objective and subjective risk part ways, Antonio's case is more complex. In effect, both possible outcomes represent different forms of risk for him, and at the same time different forms of fulfilment. Antonio's case requires a kind of casuistical accounting that leaves the nature and the very fact of risk ultimately undecidable. He therefore pushes the unmappability of risk well beyond the Greek template into realms more consonant with the mercantile conceptions of risk formulated in the medieval and early modern periods.

Antonio complicates the Hegelian understanding of risk insofar as the hazarding of life renders him at once master and slave with respect to Shylock. But Portia's case is more interesting still, since she is ambiguously master and slave with respect to risk itself. Or rather, she begins the play apparently subjected to a risk not of her own choosing and ends the play as the acknowledged master of risk - indeed, as the mortal incarnation of the goddess Fortuna herself. The risk to which Portia is initially subject is, of course, the test of the three caskets devised by her father, which deprives her of choice in marriage. That test is itself ambiguous insofar as it includes elements of pure chance while also claiming to establish a meritocracy by finding the wisest possible husband for Portia. Both of these aspects serve a mildly democratizing or levelling function by allowing Bassanio, a mere gentleman, to best a set of rivals who are exclusively of noble or royal blood. Bassanio's sole qualification seems to consist of being less ludicrous or comically unsuitable than the other suitors, but still things turn out for the best in a way that seems somehow providential.

${ }^{4}$ In his speech of parting to Bassanio, the one in which he welcomes death, Antonio observes:

For herein Fortune shows herself more kind

Than is her custom: it is still her use

To let the wretched man outlive his wealth,

To view with hollow eye and wrinkled brow

An age of poverty; from which lingering penance

Of such misery doth she cut me off. (4.1.266-271)

By saving Antonio, Portia condemns him to Fortune's "customary" end, thus reinforcing her role as Fortune. 
I say "somehow" providential, because neither Providence nor chance has much to do with the outcome of the game. As has long been recognized, Portia cheats by surreptitiously giving Bassanio the correct answer. The evidence for this is so ample and so well known as not even to merit rehearsal. Portia proves the Jacob to her father's Laban, prevailing through trickery that wins the audience's admiration rather than disapproval. What interests me here are the implications of the fact that the casket game, the play's central instance and image of risk, is rigged and hence no risk at all. Actually, this is slightly to overstate the case. Portia does not trick the first two suitors into choosing the wrong caskets. In these instances she is at risk that they may, by pure chance, happen upon the right choice. To some degree, then, a comic Providence does look out for her. But at the decisive moment she manages to defeat both chance and meritocracy by ensuring that her favoured candidate wins. In this case she becomes comic Providence herself, or at least usurps its role. Here profit and reward are distributed neither randomly nor through merit but through insider manipulation.

One result of this is to render Belmont a place at once lawful and lawless. The marrying off of Portia occurs under the guidance of her father's will - that is to say, under the aegis of paternal law. At the same time, that law accommodates a certain degree of chance insofar as it cannot prevent a lucky but unsuitable candidate from choosing the correct casket. And more to the point, it cannot prevent Portia from adhering to the rules of the game in a merely formal sense while in fact subverting them, which means that not law but her personal whim proves sovereign. Something similar happens in the Venetian courtroom, where Portia's tactics at once fulfil and negate the law. The equation of courtroom and oceanic waste occasioned by Solerio's musings points to the play's interest in spaces that are simultaneously lawful and lawless, determined and aleatory. It is Portia's gift both to create such spaces and to manipulate their ambiguities to her advantage. In so doing, she reduces risk from a legitimating force to a mere alibi, a formality or ghost that obscures her power to bend events to her will. She reveals risk to be, in the end, nothing of the sort - a mere surface appearance of the arbitrary that serves as cover for her shrewd interventions.

Similar ambiguities characterize the mythic figure of Fortuna for whom Portia increasingly comes to stand as an allegorical 
embodiment. Fortune's wheel is lawful and lawless at once, the instrument of pure chance and simultaneously of the law of chance to which all mortals must submit. Fortuna likewise occupies a kind of middle realm, not quite as transcendent as the Olympian deities yet perched above the mundane sphere she controls. The arbitrariness and determinism she simultaneously represents are somehow immanent to the world while remaining beyond its control. It is never quite clear whether Fortuna descends from above or is rather emitted from the secular realm as the mere manifestation of its own inner logic.

Portia operates as a specifically comic Fortuna. She is not a blind nemesis, reversing all positions in their turn, but one who assures a happy outcome. In some respects she simply is the conventions of comic drama instantiated as a person. Nowhere is this clearer than at the moment in act 5, scene 1 when she perfects the play's happy ending by announcing that Antonio's ships were not lost after all:

Antonio, you are welcome;

And I have better news in store for you

Than you expect: unseal this letter soon;

There you shall find three of your argosies

Are richly come to harbour suddenly:

You shall not know by what strange accident

I chanced on this letter. (5.1.273-279)

Portia's speech combines two miracles: the unexpected arrival of Antonio's ships and the inexplicable means by which she becomes bearer of this news. Her final two lines, "you shall not know by what strange accident | I chanced on this letter," are directed specifically at Antonio but more generally at the play's audience, who are informed that even romance comedy's loose standards of verisimilitude are now being violated in a way that will receive no explanation. Nowhere else does Portia seem less like a human character and more like a force of divine intervention, as if the goddess Fortuna herself momentarily burst out of her human disguise. Not only does Portia subvert the laws of Belmont and Venice; here she subverts the law of dramatic believability as she momentarily verges on becoming somehow too blatantly comic, too providential. She occupies a liminal realm at once inside the fiction of the play and outside it, visibly manipulating comedy's structuring mechanisms. And not incidentally, in so doing she retroactively 
evaporates any sense of risk. If things always turn out for the best, if a governing Providence assures that the finest people are always rewarded, then the risks they undertake are mere seeming, destined to be negated after the fact.

This is perhaps a good thing for comic drama, but it has complicated effects when applied to mercantile risk, which has the ideological task of justifying mercantile profit. On the one hand, it suggests that the successful negotiation of risk indicates divine election. Rejecting Shylock's parable of Jacob and Laban, Antonio states:

This was a venture, sir, that Jacob served for;

A thing not in his power to bring to pass,

But sway'd and fashion'd by the hand of heaven. (1.3.88-90)

Likewise, as he is about to choose in the game of the caskets, the Prince of Morocco prays "Some god direct my judgment!" (2.7.13). The notion that apparent risk or chance reveals the elect of God does justify mercantile profit, but in an older, theological mode. If Portia is indeed the vessel of some divine providence, this ratifies the outcome not only of the casket game but of the play as a whole, in which the worthy are rewarded.

And yet this divine transcendence is always haunted by a bad immanence: the possibility that the rules of the game are not being regulated by an outside beneficent force but rather manipulated to Portia's own advantage and that of the other players she favours by one of the participants who should be subject to those rules. If risk is negated not by an outsider but by a privileged insider, then what might otherwise look like justice comes to seem like naked selfinterest. And of course, what makes The Merchant of Venice such an interesting problem comedy is the pervasive sense that the characters who come out on top are not "the best" in any moral sense but simply the wealthy, attractive members of an in-group who make sure that their own kind profit at the expense of marginalized outsiders such as Shylock.

I think I have sufficiently tipped my hand by this point to make the central conceit of this paper explicit. What is that peculiar kind of space imagined by Shakespeare's play - a space at once anarchic and lawful, dangerous yet ultimately comic, governed by a kind of immanent providence that converts chance into merit and rewards 
the risky, yet a space constantly haunted by the possibility that all of this is mere appearance concealing manipulation? What is this space but the space of the market itself, its governing providence nothing other than what Adam Smith would later call the Invisible Hand? Within The Merchant of Venice, the role of Invisible Hand is played by Portia/Fortuna, who represents both good and bad forms of immanence. As the characterological incarnation of comic convention, Portia displays a wit and initiative that enable the play's social world to surmount its conflicts and achieve the status of happily self-governing order. But at the same time, she manifests the self-serving quality of such manipulation. She is, in effect, the first inside trader.

I recognize that such blatant allegoresis runs the risk of turning into self-parody, if it has not already done so. A wiser critic than I might well turn back at this point and let well enough alone. But for better or worse, I cannot resist the temptation of pushing things further still, and I shall do so by turning to the character of Bassanio. Bassanio appears to more discerning readers of the play as an empty-headed character who appeals to Portia based on his good looks alone. Certainly someone who compares his wooing of Portia to Jason's pursuit of the Golden Fleece is unlikely to possess the wisdom required to pick the leaden casket without help. But I think that Bassanio's fecklessness has not been sufficiently appreciated. Not only is he willing to put Antonio at mortal risk in order to squeeze more money out of him, but the pretences under which he does so are misleading at best, beginning with the simile of the two arrows with which he attempts to persuade Antonio of the wisdom of lending him still more money:

In my school-days, when I had lost one shaft,

I shot his fellow of the self-same flight

The self-same way with more advised watch,

To find the other forth, and by adventuring both

I oft found both: I urge this childhood proof,

Because what follows is pure innocence.

I owe you much, and, like a willful youth,

That which I owe is lost; but if you please

To shoot another arrow that self way

Which you did shoot the first, I do not doubt,

As I will watch the aim, or to find both

Or bring your latter hazard back again

And thankfully rest debtor for the first. (1.1.140-152) 
Depicting Portia, that "lady richly left," as a means of repaying Antonio is disturbing enough. In fact, however, Bassanio's pursuit of Portia is no sure thing. Shylock inadvertently recalls and critiques Bassanio's image after the flight of Jessica: "No news of them? Why, so! And I know not what spent in the search. Why thou loss upon loss - the thief gone with so much, and so much to find the thief!" (3.1.86-89). Even more disturbing, though, it is by no means obvious that the money borrowed from Antonio plays any significant role in the winning of Portia. For one thing, as far as Bassanio knows, her marriage is determined by the game of the caskets, not by personal choice, so there is no need to woo her with lavish spending. Later in the play, moreover, Bassanio reminds her that

When I did first impart my love to you,

I freely told you, all the wealth I had

Ran in my veins, I was a gentleman. (3.2.253-255)

In other words, Portia knows from the start that Bassanio is without means and seems not to care. His spending would therefore seem to have more to do with impressing the other suitors and keeping up appearances for them than it does with Portia. Finally, most of the borrowed money seems to be spent in Venice rather than Belmont. Bassanio does mention sending a servant to Portia bearing "gifts of rich value" (2.9.90), but he also mentions feasting his "best esteemed acquaintance" (2.2.170) in Venice, of buying rich new liveries for his servants, and of adding Launcelot to his retinue and furnishing him with the most expensive livery of all. Bassanio puts his best friend's life at risk, then, neither to win Portia nor to repay his debts to Antonio thereby, but for the most part just to continue his ongoing spending spree. What I am tempted to call Bassanio's bailout does not achieve a reformation of his profligate habits but simply allows him to perpetuate them. Bassanio is simply too big to fail, just as Antonio is too good to fail, and so the play finds itself committed to covering their respective debts. In the world of comic drama, fortunately, new funds and newly-saved ships can be conjured up at the stroke of a pen. Shakespeare's play initially makes up Antonio's losses by having the Duke appropriate Shylock's wealth, thereby reminding us at least that someone else might suffer devastating loss in order to cover Antonio's bets. That three of his ships eventually come in, meaning that the expropriation of Shylock's wealth was unnecessary after all, simply rubs salt in the wounds. This debt, like Bassanio's, didn't really need to be paid. If the merchant's profits are 
justified by his undergoing risk, then Antonio should have been allowed to absorb his loss. That he too is bailed out unnecessarily casts doubt on the underlying logic of the entire system.

In his book Risk Society, which became something of an instant classic, the German sociologist Ulrich Beck argues that the production and distribution of risk is both an engine of modernization and one of its underlying, seemingly insoluble problems. Beck (1992:12) divides capitalist modernity into two phases: in the first, marked by industrialization, "the 'logic' of wealth production dominates the 'logic' of risk production." In the second phase or risk society, "this relation is reversed." One of the consequences of this transition is that risk becomes increasingly difficult to map.

Anyone who set out to discover new countries and continents like Columbus - certainly accepted "risks." But these were personal risks, not global dangers like those that arise for all humanity from nuclear fusion or the storage of radioactive waste. In that earlier period, the word risk had a note of bravery and adventure, not the threat of self-destruction of all life on earth (Beck 1992:21).

In early mercantile and entrepreneurial endeavour, subjective and objective risks coincide, just as they do for the Hegelian master. The one who wishes to recoup wealth is the one who must personally undergo risk, and this invests him with a quasi-heroic character. As modernity becomes increasingly advanced and selfreflexive, however, risks are distributed in ways that become increasingly difficult to map:

Everyone is cause and effect, and thus non-cause. The causes dribble away into a general amalgam of agents and conditions, reactions and counter reactions, which brings social certainty and popularity to the concept of system. This reveals in exemplary fashion the ethical significance of the system concept: one can do something and continue doing it without having to take personal responsibility for $i t$. It is as if one were acting while being personally absent. (Beck 1992:33)

As Beck points out, the notion of systemic risk is both necessary to comprehend the dynamics of modernity and an appealing alibi for those who wish to evade responsibility for generating risks. The unmappability of risk provides a kind of cover; it can rarely be proven, for instance, that a given particular carcinogen caused a 
given individual case of cancer, and so the perpetrator escapes responsibility. Modern risk is not only untraceable, moreover, but invisible as well. "The risks of civilization today typically escape perception and are localized in the sphere of physical and chemical formulas (e.g. toxins in the foodstuffs or the nuclear threat)" (1992:21). Beck describes such risks as "the stowaways of normal consumption" (1992:40). The invisibility of modern toxins produces objective risk with no subjective counterpart other than perhaps a generalized wariness toward the food supply in some well-educated sectors of society. But if this disequilibrium between subjective and objective risk results in something like tragic irony, it is an irony which, unlike that of Oedipus and Pentheus, never comes to light.

The general unmappability of risk in advanced modernity abets a redistribution of risk that is in part unplanned and in part planned. While the Renaissance merchant proudly assumes his risk, the owner of the chemical company is at no greater danger from its toxic by-products than any other citizen - quite possibly less so, given the ability of wealthier and better-educated strata to reduce their own environmental risks while increasing them for others. In effect, the redistribution of risks is the dystopian counterpart to, and inversion of, the redistribution of wealth which capitalism makes sure will never happen.

One way of understanding the relation between industrial and risk societies involves shifting relations between risk and wealth. In the industrial and pre-industrial phases, the appropriation of profit and the endurance of personal risk coincide - if not always in fact, then at least as alibi and ideological justification. In risk society, the possibility of loss is still invoked as an alibi for profit, but this alibi becomes increasingly hollow as not only environmental but even economic risk itself is displaced onto others. Beck (1992:147) notes, for instance, that "portions of entrepreneurial risk can be shifted onto the employees as flexible underemployment." Even this, however, keeps the displacement of economic risk within the confines of the firm - from employers to employees - and thus merely updates the older forms of capitalist exploitation analysed by Marx. The financial crisis of 2008 , however, raised this redistribution to a new level, displacing the consequences of truly insane levels of financial risk onto the population at large, and particularly its most vulnerable sectors. It is as if economic risk finally achieved the same 
kinds of generalized dispersal previously associated only with environmental hazards.

All of this lies in a future too distant for even Shakespeare to imagine. And yet, I would argue, some of the fundamental logics of this process are already laid bare in The Merchant of Venice. The bailout of a highly leveraged Bassanio by Antonio, and the bailout of an even more heavily leveraged Antonio by Portia, aided by the Venetian state as the agency of risk redistribution, ends up looking oddly prescient. Above all the coincidence of good and bad forms of immanence in Portia dramatizes a secular form of comic providence which, under closer inspection, manipulates, displaces, and redistributes risk for the benefit of a social coterie.

I want to conclude with a few words on Mercy, the subject of Portia's famous courtroom speech in Act IV. The ideals expressed in this speech are of course negated by the subsequent treatment of Shylock, whose life is spared, true, but who is stripped of his wealth, forcibly converted, and who practically staggers offstage under the force of this double blow. But I wonder whether a different problem with mercy was not revealed in the aftermath of the financial crisis of 2008, when none of the principals who drove the world's economy off a cliff were prosecuted for their offenses. Here too the distribution of mercy was highly selective: little or none for those who lost homes, jobs, and life savings, but an unspoken blanket amnesty for the wealthy bankers and speculators who caused this misery. In Shakespeare's play, too, the real problem with Mercy may lie not only in the one character to whom it is not applied, but perhaps even more fundamentally in those to whom it is. The financial crisis of The Merchant of Venice, like that of 2008, allows the play's "golden" characters to get off scot free, both in a practical sense and in the sympathies of the audience. Perhaps Shakespeare's most powerful lesson about mercy, then, is not that it is "mightiest in the mightiest," as Portia puts it, but rather that is it also (and for the very same reason) mightiest toward the mightiest. 


\section{References}

Beck, Ulrich 1992. Risk Society: Towards a New Modernity. Trans. Mark Ritter. London: SAGE Publications.

Collas-Heddeland, Emmanuelle, Odile Kammerer, and Alain J. Le Maître 2004. "Moyen Age et Temps Moderne: L'ère du calcul." Pour une Histoire Culturelle du Risque. Strasbourg: Université de Haute-Alsace.

Daniel, Drew 2013. "Let Me Have Judgment, and the Jew His Will." The Melancholy Assemblage: Affect and Epistemology in the English Renaissance. New York: Fordham University Press: 92-119.

Ferber, Michael 1990. "The Ideology of The Merchant of Venice." English Literary Renaissance 20/3: 431-464.

Kojève, Alexandre 1980. Introduction to the Reading of Hegel: Lectures on the Phenomenology of Spirit. Ed. Alan Bloom. Ithaca: Cornell University Press.

Piron, Sylvain 2004. "L'apparition du resicum en Méditerranée occidentale au XIIème-XIIIème siècles." Eds. Emmanuelle Collas-Hedeland et al. Pour une Histoire Culturelle du Risque: Genèse, Évolution, Actualité du Concept dans le Sociétés Occidentales. Strasbourg: Université de Haute-Alsace.

Shakespeare, William 2004. The Complete Works of Shakespeare. Ed. David Bevington. New York: Pearson Longman.

Wood, Peter 2011. "The Merchant of Zuccotti Park." The Chronicle of Higher Education. <url: http://chronicle.com/blogs/innovations/the-merchantof-zuccotti-park/30865>. Last accessed 28/o1/2014.

How to cite this article:

Halpern, Richard. "Bassanio's bailout: A brief history of risk, Shakespeare to Wall Street." SEDERI 24 (2014): 27-45.

Author's contact: r.l.halpern@att.net

Submission: 18/09/2013

Acceptance: 20/01/2014 